\title{
Extraction methods and availability of micronutrients for wheat under a no-till system with a surface application of lime
}

\author{
Adriel Ferreira da Fonseca'; Eduardo Fávero Caires ${ }^{1 *}$; Gabriel Barth ${ }^{2}$ \\ ${ }^{1}$ UEPG - Depto de Ciência do Solo e Engenharia Agrícola - 84030-900 - Ponta Grossa, PR - Brasil. \\ ${ }^{2}$ FUNDAÇÃO ABC - Setor de Fertilidade do Solo - 84165-980 - Castro, PR - Brasil. \\ *Corresponding author <efcaires@uepg.br>
}

\begin{abstract}
Micronutrient availability can be affected by the increase of the soil $\mathrm{pH}$ due to surface liming. A field trial was carried out on a loamy, kaolinitic, thermic Typic Hapludox at Ponta Grossa, Paraná State, Brazil. The main objective was to evaluate the effects of surface liming and re-liming on the availability of micronutrients [copper $(\mathrm{Cu})$, iron $(\mathrm{Fe})$, manganese $(\mathrm{Mn})$, and zinc $(\mathrm{Zn})$ ] for wheat (Triticum aestivum L.) cropped under a no-till system. A randomized complete block design was used in a split-plot arrangement. The main plots received surface lime applications $\left(2,4\right.$, and $\left.6 \mathrm{Mg} \mathrm{ha}^{-1}\right)$ in July 1993. In the subplots, surface lime (3 $\mathrm{Mg} \mathrm{ha}^{-1}$ ) was applied again in June 2000. In 2003, before the wheat sowing, soil samples were taken at 0-5, 510 , and 10-20 cm layers. Soil cationic micronutrients concentrations using different extractants (DTPA-TEA, Mehlich-1, HCl, and Mehlich-3) and solution/soil ratios were determined. Application of lime increased soil $\mathrm{pH}$ at $0-5,5-10$, and $10-20 \mathrm{~cm}$. The increase in soil $\mathrm{pH}$ by liming did not affect soil organic carbon content. The Mehlich-3 solution had a greater capacity in extracting soil micronutrients. Increasing solution/soil ratio of the DTPA-TEA, Mehlich-1, and $\mathrm{HCl}$ solutions generally increased the extraction of $\mathrm{Cu}, \mathrm{Fe}, \mathrm{Mn}$, and $\mathrm{Zn}$. Liming and re-liming caused a decrease in Mn concentration in the wheat leaves. Leaf concentrations of $\mathrm{Cu}$, $\mathrm{Fe}$ and $\mathrm{Zn}$ were not affected by liming treatments. The solutions of DTPA-TEA, Mehlich-1, HCl, and Mehlich-3 were ineffective to predict the soil cationic micronutrients availability for a wheat crop after surface application of lime.

Key words: Triticum aestivum L., soil acidity, dolomitic lime, multinutrient extractants, soil with variable charge
\end{abstract}

\section{Métodos de extração e disponibilidade de micronutrientes para o trigo cultivado em plantio direto com calagem na superfície}

\begin{abstract}
RESUMO: A disponibilidade de micronutrientes pode ser alterada pelo aumento no $\mathrm{pH}$ do solo proporcionado pela calagem superficial. Os efeitos da calagem e da reaplicação de calcário na superfície sobre a disponibilidade de micronutrientes [cobre $(\mathrm{Cu})$, ferro $(\mathrm{Fe})$, manganês $(\mathrm{Mn})$ e zinco $(\mathrm{Zn})$ ] para o trigo (Triticum aestivum $\mathrm{L}$.) foram estudados em um Latossolo Vermelho textura média sob plantio direto, em Ponta Grossa (PR). O delineamento experimental empregado foi o de blocos completos ao acaso com parcelas subdivididas. As parcelas receberam calagem superficial $\left(2,4\right.$ e $\left.6 \mathrm{Mg} \mathrm{ha}^{-1}\right)$ em julho de 1993 . O calcário $\left(3 \mathrm{Mg} \mathrm{ha}^{-1}\right)$ foi reaplicado nas subparcelas em junho de 2000. Antes da semeadura do trigo em 2003, retiraram-se amostras de solo nas camadas de 0-5, 5-10 e 10-20 cm e determinaram-se os micronutrientes catiônicos com diferentes extratores (DTPA-TEA, Mehlich-1, HCl e Mehlich-3) e relações solução/solo. A calagem aumentou o pH do solo nas camadas de 0-5, 5-10 e 10-20 cm, mas não alterou o carbono orgânico. O extrator Mehlich-3 apresentou maior capacidade de extração de micronutrientes catiônicos. $\mathrm{O}$ aumento da relação solução/solo dos extratores DTPA-TEA, Mehlich-1 e HCl geralmente aumentou a extração de $\mathrm{Cu}$, Fe, $\mathrm{Mn}$ e Zn. A calagem e a reaplicação do calcário diminuíram a concentração de $\mathrm{Mn}$ nas folhas de trigo. Os teores foliares de $\mathrm{Cu}, \mathrm{Fe}$ e $\mathrm{Zn}$ não foram alterados pela calagem. As soluções de DTPA-TEA, Mehlich-1, $\mathrm{HCl}$ e Mehlich-3 foram ineficientes para prever a disponibilidade de micronutrientes catiônicos para o trigo, após aplicação superficial de calcário.

Palavras-chave: Triticum aestivum L., acidez do solo, calcário dolomítico, extratores multinutrientes, solo com carga variável
\end{abstract}

\section{Introduction}

Surface application of lime without incorporation has been the usual practice to control soil acidity in notill (NT) systems (Caires et al., 2005). However, surface liming can decrease the cationic micronutrients availability as a consequence of increasing soil $\mathrm{pH}$ at the most superficial layers of the soil (Caires \& Da Fonseca, 2000; Godsey et al., 2007).
Studies related to bioavailability of cationic micronutrients in Brazilian soils have been carried out in pots under greenhouse conditions or in field trials under conventional tillage systems (Camargo et al., 1982; Bataglia \& Raij, 1989; Abreu et al., 1994, 1996, 1998, 2002; Rodrigues et al. 2001; Nascimento et al., 2006). In no-till systems, soil organic matter and cationic micronutrients concentrations have been higher up to $10 \mathrm{~cm}$ depth (Zanão Júnior et al., 2007). Because the surface-applied

Sci. Agric. (Piracicaba, Braz.), v.67, n.1, p.60-70, January/February 2010 
lime under NT systems has been more effective in increasing $\mathrm{pH}$ near the soil surface (Caires et al., 2005), more information is necessary concerning the effects of liming on cationic micronutrient bioavailability in this cropping system. In addition, well-known extractants, i.e. chelating and/or acid solutions reported in Norvell (1984) and Abreu et al. (2007), must be more studied under NT systems to identify the more appropriated soil micronutrient extractant.

From the economic point of view wheat is, one of the most important winter crops in Southern Brazil. Therefore, the wheat crop was chosen to be used in this study to evaluate the effects of surface liming and re-liming in a long term NT system on availability of cationic micronutrients $(\mathrm{Cu}, \mathrm{Fe}, \mathrm{Mn}$, and $\mathrm{Zn})$. Different extractants and soil/solution ratios were evaluated, as well as the micronutrients concentrations in wheat leaves to determine the most appropriated soil extractants for available cationic micronutrients in this crop production system.

\section{Material and Methods}

The experiment was carried out in Ponta Grossa, PR,

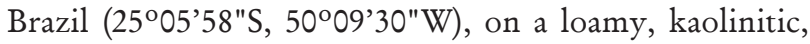
thermic Typic Hapludox. Before the establishment of the experiment (May 1993 ) soil chemical and particle size analyses of the topsoil $(0-20 \mathrm{~cm})$ showed the following results: $\mathrm{pH}$ [1:2.5 soil: $0.01 \mathrm{~mol} \mathrm{~L}^{-1}$ calcium chloride $\left.\left(\mathrm{CaCl}_{2}\right)\right]$ : 4.5; exchangeable $\mathrm{Al}^{3+}, \mathrm{Ca}^{2+}, \mathrm{Mg}^{2+}$, and $\mathrm{K}^{+}: 6$, 16,10 , and $1.4 \mathrm{mmol}_{\mathrm{c}} \mathrm{dm}^{-3}$, respectively; total acidity $\mathrm{pH}$ $7.0(\mathrm{H}+\mathrm{Al}): 58 \mathrm{mmol} \mathrm{dm}^{-3}$; P (Mehlich-1): $9.0 \mathrm{mg} \mathrm{dm}^{-3}$; soil organic carbon (SOC): $19 \mathrm{~g} \mathrm{dm}^{-3}$; base saturation $32 \%$; clay, silt, and sand: 295,240 , and $465 \mathrm{~g} \mathrm{~kg}^{-1}$ respectively. The clay fraction of the soil had $265.8 \mathrm{~g} \mathrm{~kg}^{-1}$ of kaolinite, $26.8 \mathrm{~g} \mathrm{~kg}^{-1}$ goethite, and $2.4 \mathrm{~g} \mathrm{~kg}^{-1}$ hematite. At the beginning of the experiment, the field site had been used for grain cropping under NT system during the previous $15 \mathrm{yr}$.

A randomized complete block design, with three replications in a split-plot arrangement was used. The main plots $(8.0 \mathrm{~m} \times 6.3 \mathrm{~m})$ treatment consisted of a surface dolomitic lime broadcasting at the rates of $0,2,4$, and 6 $\mathrm{Mg} \mathrm{ha}{ }^{-1}$ in July 1993. The lime rates were calculated to raise the base saturation in the topsoil $(0-20 \mathrm{~cm})$ to 50 , 70 and $90 \%$ base saturation. The dolomitic lime used contained $176 \mathrm{~g} \mathrm{~kg}^{-1} \mathrm{Ca}, 136 \mathrm{~g} \mathrm{~kg}^{-1} \mathrm{Mg}$, and $84 \%$ effective calcium carbonate equivalent (ECCE). Approximately, seven years later (in June 2000) the main plots were subdivided in two subplots $(4.0 \mathrm{~m} \times 6.3 \mathrm{~m})$ to study the influence of surface re-liming $\left(196 \mathrm{~g} \mathrm{~kg}^{-1} \mathrm{Ca}, 130 \mathrm{~g} \mathrm{~kg}^{-1} \mathrm{Mg}\right.$, and $90 \%$ ECCE) at the rates of 0 and $3 \mathrm{Mg} \mathrm{ha}^{-1}$. The reliming highest rate was calculated to raise the topsoil base saturation to $65 \%$ (Caires et al., 2000) regarding the treatment on which were applied $4 \mathrm{Mg} \mathrm{ha}^{-1}$ of lime in July $1993\left[\mathrm{pH} 0.01 \mathrm{~mol} \mathrm{~L}^{-1} \mathrm{CaCl}_{2}\right.$ of 4.6; cation exchange capacity (CEC) at pH 7.0 of $110.8 \mathrm{mmol}_{\mathrm{c}} \mathrm{dm}^{-3}$; and $41 \%$ of base saturation].
The experimental area has been fertilized with $\mathrm{N}$, $\mathrm{P}$, and $\mathrm{K}$, without addition of cationic micronutrients. Soybean [Glycine max (L.) Merr.] or corn (Zea mays L.) in the spring-summer season, and wheat or triticale $(x$ Triticosecale) or black oat (Avena strigosa Schreb.) in the autumn-winter season has been cultivated. More details about the historic of cropping and fertilization and the effects of surface application of lime in the soil-plant system was reported elsewhere (Caires et al. 2005).

Wheat, cv. CD 104 (moderately susceptible to the soil exchangeable $\mathrm{Al}^{3+}$ ) was sown in June 2003, with $17 \mathrm{~cm}$ between rows and $140 \mathrm{~kg}$ of seed per hectare, for a population between 250 and 300 plants $\mathrm{m}^{-2}$. Fertilizers were applied by top dressing at the rates of $80 \mathrm{~kg} \mathrm{ha}^{-1} \mathrm{~N}$ and $35 \mathrm{~kg} \mathrm{ha}^{-1} \mathrm{~K}$, as ammonium nitrate and potassium chloride, respectively.

Wheat plants flowered fully 84 days after emergence, and the crop maturation occurred 126 days after emerging. Air temperature was adequate for wheat growing and rainfall was on a considerable amount before sowing $(55 \mathrm{~mm})$ and before the plant flowering stage (56 $\mathrm{mm})$. However, there was an extended water deficit during the vegetative development stage. Rainfall was 434 $\mathrm{mm}$ during the wheat crop cycle. More details about the wheat crop management are in Caires et al. (2006b).

During the flowering period of the wheat crop, leaves were sampled from 30 plants (flag leaf standard) of each subplot (Bataglia et al., 1978). These samples were washed in de-ionized water, dried in a forced-air oven at $60^{\circ} \mathrm{C}$ until constant mass was achieved, and ground in a Wiley type mill to pass a $0.75 \mathrm{~mm}$ screen. After nitric-perchloric acid digestion of the plant tissues, $\mathrm{Cu}, \mathrm{Fe}$, $\mathrm{Mn}$, and $\mathrm{Zn}$ concentrations were determined by atomic absorption spectrophotometry, according to Malavolta et al. (1997).

In May 2003, before wheat sowing - ten years after surface liming and three years after surface re-liming soil samples were taken at 0-5, 5-10, and $10-20 \mathrm{~cm}$ layers. Twelve soil core samples per subplot were taken with a soil probe sampler and mixed to obtain a composite sample, which was air dried, and crushed to pass a 2$\mathrm{mm}$ sieve. Soil $\mathrm{pH}$ and SOC were determined according to procedures suggested by Pavan et al. (1992). Soil available contents of $\mathrm{Cu}, \mathrm{Fe}, \mathrm{Mn}$ and $\mathrm{Zn}$ were extracted using the following procedures:

a) Method-1 [DTPA-TEA solution (2:1)]: Ten $\mathrm{cm}^{3}$ of air dried soil $+20 \mathrm{~mL}$ of extracting solution were shaken during $2 \mathrm{~h}$. Soil extracts (2:1 extractant/soil ratio) were obtained with DTPA-TEA $\left(0.005 \mathrm{~mol} \mathrm{~L}^{-1}\right.$ diethylenetriaminepentaacetic acid $+0.1 \mathrm{~mol} \mathrm{~L}^{-1}$ triethanolamine $+0.01 \mathrm{~mol} \mathrm{~L}^{-1} \mathrm{CaCl}_{2}$ ) solution at $\mathrm{pH} 7.3$ as described by Lindsay \& Norvell (1978). This is the method used by some Brazilian laboratories, adopting the "IAC System of Soil Analysis" (Abreu et al., 1998)].

b) Method-2 [DTPA-TEA solution (5:1)]: Ten $\mathrm{cm}^{3}$ of air dried soil $+50 \mathrm{~mL}$ of extracting solution were shaken for $2 \mathrm{~h}$. Soil extracts [5:1 extractant/soil ratio, ac- 
cording to Norvell (1984)] were obtained with DTPATEA solution at pH 7.3 (Lindsay \& Norvell, 1978).

c) Method-3 [Mehlich-1 solution (5:1)]: Five $\mathrm{cm}^{3}$ of air dried soil $+25 \mathrm{~mL}$ of extracting solution were shaken for $5 \mathrm{~min}$. Soil extracts (5:1 extractant/soil ratio) were obtained with Mehlich-1 $[0.05$ mol L-1 hydrochloric acid $(\mathrm{HCl})+0.0125 \mathrm{~mol} \mathrm{~L}^{-1}$ sulfuric acid $\left.\left(\mathrm{H}_{2} \mathrm{SO}_{4}\right)\right]$ solution. This procedure is widely used by many laboratories in Brazil for determination of micronutrients (Bernardi et al., 2002).

d) Method-4 [Mehlich-1 solution (10:1)]: Two and onehalf $\mathrm{cm}^{3}$ of air dried soil $+25 \mathrm{~mL}$ of extracting solution were shaken for $5 \mathrm{~min}$. Soil extracts (10:1 extractant/soil ratio) were obtained with Mehlich-1 solution. This procedure is widely used by many laboratories in Brazil as a multinutrient extractant (Abreu et al., 1998).

e) Method-5 [ $\mathrm{HCl}$ solution (5:1)]: Five $\mathrm{cm}^{3}$ of air dried soil $+25 \mathrm{~mL}$ of extracting solution were shaken for 30 min. Soil extracts $(5: 1$ extractant/soil ratio) were obtained with $0.1 \mathrm{~mol} \mathrm{~L}^{-1} \mathrm{HCl}$ solution as described by Osiname et al. (1973).

f) Method-6 [HCl solution (10:1)]: Two and one-half $\mathrm{cm}^{3}$ of air dried soil $+25 \mathrm{~mL}$ of extracting solution were shaken for of $30 \mathrm{~min}$. Soil extracts (10:1 extractant/soil ratio) were obtained with $0.1 \mathrm{~mol} \mathrm{~L}^{-1} \mathrm{HCl}$ solution as described by Osiname et al. (1973).

g) Method-7 [Mehlich-3 solution]: Two and one-half $\mathrm{cm}^{3}$ of air dried soil $+25 \mathrm{~mL}$ of extracting solution were shaken for $5 \mathrm{~min}$. Soil extracts (10:1 extractant/soil ratio) were obtained with Mehlich-3 $\left[0.2 \mathrm{~mol} \mathrm{~L}^{-1}\right.$ acetic acid $\left(\mathrm{CH}_{3} \mathrm{COOH}\right)+0.25 \mathrm{~mol} \mathrm{~L}^{-1} \mathrm{NH}_{4} \mathrm{NO}_{3}+0.015 \mathrm{~mol} \mathrm{~L}^{-1}$ ammonium fluoride $\left(\mathrm{NH}_{4} \mathrm{~F}\right)+0.013 \mathrm{~mol} \mathrm{~L}{ }^{-1}$ nitric acid $\left(\mathrm{HNO}_{3}\right)+0.001 \mathrm{~mol} \mathrm{~L}^{-1}$ ethylenediaminetetraacetic acid (EDTA)] solution at $\mathrm{pH} 2.5$ as described by Mehlich (1984).

All soil extracting solution suspensions were shaken on a horizontal-circular shaking machine at $220 \mathrm{rpm}$. After this step, all suspensions were filtered through Whatman \#42 filter paper and the concentration of micronutrients were measured using a PerkinElmer Optima $3000 \mathrm{XL}$ simultaneous inductively coupled plasma optical emission spectrometry (ICP-OES), under routine operating conditions, at the $324.754 \mathrm{~nm}, 259.940 \mathrm{~nm}$, $257.610 \mathrm{~nm}$, and $213.856 \mathrm{~nm}$ atomic lines for $\mathrm{Cu}, \mathrm{Fe}, \mathrm{Mn}$, and $\mathrm{Zn}$, respectively.

Soil and plant data were submitted to variance and regression analyses. Regression equations were adjusted to the obtained data according to lime rates $(0,2,4$, and 6 $\left.\mathrm{Mg} \mathrm{ha}^{-1}\right)$, adopting the magnitude of coefficients of determination $(p<0.05)$ as the criteria of choice. The effects of re-liming at 0 and $3 \mathrm{Mg} \mathrm{ha}^{-1}$ were compared by the Tukey test $(p=0.05)$. When a no significant interaction of the liming versus the re-liming treatment was observed, the effects of treatments were compared by using their means. Simple linear correlation analyses
(Pearson correlation, $p<0.05)$ were obtained for soil $\mathrm{pH}$ and cationic micronutrients extracted by different procedures. All statistical analyses were performed using the SAS program, version 8.02 (SAS Institute, 1999).

\section{Results and Discussion}

\section{Soil organic carbon and soil reaction}

No interactions were observed between the surface liming rates $\left(0,2,4\right.$, and $\left.6 \mathrm{Mg} \mathrm{ha}^{-1}\right)$ and surface re-liming $\left(0\right.$ and $3 \mathrm{Mg} \mathrm{ha}^{-1}$ ) for SOC and soil $\mathrm{pH}$. Surface liming and re-liming did not cause changes in the SOC concentrations. The mean concentrations of SOC at 0-5, 5-10 and $10-20 \mathrm{~cm}$ layers were $25.1,19.2$ and $17.7 \mathrm{~g} \mathrm{dm}^{-3}$, respectively. Caires et al. (2006a) reported similar results for other Oxisol (clayey, kaolinitic, thermic Rhodic Hapludox) under a NT system.

Soil $\mathrm{pH}(\hat{y})$ increased linearly with increasing surface liming rate $\left(x\right.$, in $\left.\mathrm{Mg} \mathrm{ha} \mathrm{h}^{-1}\right)$ in the folowing layers: 0 $5 \mathrm{~cm}\left(\hat{y}=4.85+0.14 x, \mathrm{R}^{2}=0.98\right), 5-10 \mathrm{~cm}(\hat{y}=4.31$ $\left.+0.13 x, \mathrm{R}^{2}=0.99\right)$ and $10-20 \mathrm{~cm}\left(\hat{y}=4.32+0.07 x, \mathrm{R}^{2}\right.$ $=0.97)$. Surface re-liming increased significantly soil $\mathrm{pH}$ from 4.9 to $5.7,4.6$ to 4.8 , and 4.5 to 4.6 at the $0-5,5-10$ and $10-20 \mathrm{~cm}$ layers, respectively. More details about the effects of surface liming on the soil chemical attributes are related elsewhere (Caires et al., 2006b).

The availability of micronutrients to the crops is controlled by many soil factors such as $\mathrm{pH}$, soil organic matter, temperature, and moisture (Fageria et al., 2002). In this study, because the wheat crop presented adequate growth and yield (Caires et al., 2006b) and SOC concentrations were unchanged due to liming treatments, soil $\mathrm{pH}$ was assumed to be the major factor on determining the bioavailability of $\mathrm{Cu}, \mathrm{Fe}, \mathrm{Mn}$, and $\mathrm{Zn}$.

\section{Extractable cationic micronutrients}

Soil extractable $\mathrm{Cu}$, for all extraction methods, was not influenced by the interaction between lime rates $(0$, 2,4 , and $6 \mathrm{Mg} \mathrm{ha}^{-1}$ ) and re-liming $\left(0\right.$ and $\left.3 \mathrm{Mg} \mathrm{ha}^{-1}\right)$. Copper concentrations decreased linearly with increasing lime application rates for DTPA-TEA solution (5:1), Mehlich-1 solution (5:1 and 10:1) and $\mathrm{HCl}$ solution (5:1 and 10:1) at $0-5 \mathrm{~cm}$ layer; and also by $0.1 \mathrm{~mol} \mathrm{~L}^{-1} \mathrm{HCl}$ solution (5:1) at 5-10 cm layer (Figure 1). Negative correlations were observed between concentrations of extractable $\mathrm{Cu}$ and soil $\mathrm{pH}$, mainly, at $0-5 \mathrm{~cm}$ layer (Table 1). Solubility of $\mathrm{Cu}^{2+}$ is soil $\mathrm{pH}$ dependent and decreases 100-fold for each unit increase in $\mathrm{pH}$ (Fageria et al., 2002). Moreover, these authors also state that increases in soil $\mathrm{pH}$ above 6.0 induces hydrolysis of hydrated $\mathrm{Cu}$ which can lead to a stronger $\mathrm{Cu}$ adsorption by the clay minerals and organic matter.

Unusual effects were also observed and associated with liming; e.g. quadratic increase of the $\mathrm{Cu}$ concentrations extracted by DTPA-TEA solution $(2: 1)$ at $0-5 \mathrm{~cm}$ layer; by DTPA-TEA solution (2:1 and 5:1), Mehlich-1 solution (5:1 and 10:1) and Mehlich-3 solution at $5-10 \mathrm{~cm}$ layer; and, by $0.1 \mathrm{~mol} \mathrm{~L}^{-1} \mathrm{HCl}$ solution (10:1) at 10-20 $\mathrm{cm}$ layer (Figure 1). A possible explanation for these ef- 
Table 1 - Coefficients of correlation between soil $\mathrm{pH}$ and micronutrients concentrations extracted by different methods, at $0-5,5-10$ and $10-20 \mathrm{~cm}$ layers.

\begin{tabular}{|c|c|c|c|c|}
\hline \multirow{2}{*}{ Method } & \multicolumn{4}{|c|}{ Extractable micronutrient } \\
\hline & Copper $(\mathrm{Cu})$ & Iron $(\mathrm{Fe})$ & Manganese $(\mathrm{Mn})$ & Zinc $\left(Z_{n}\right)$ \\
\hline \multicolumn{5}{|l|}{$0-5 \mathrm{~cm}$ layer } \\
\hline Method-1 ${ }^{(1)}$ & $-0.54 * *$ & $-0.91 * *$ & $-0.35^{\mathrm{NS}}$ & $0.20^{\mathrm{NS}}$ \\
\hline Method-2(2) & $-0.61 * *$ & $-0.86^{* *}$ & $-0.14^{\mathrm{NS}}$ & $0.24^{\mathrm{NS}}$ \\
\hline Method-3 ${ }^{(3)}$ & $-0.83^{* *}$ & $-0.85^{* *}$ & $-0.29^{\mathrm{NS}}$ & $0.20^{\mathrm{NS}}$ \\
\hline Method-4(4) & $-0.84^{* *}$ & $-0.89 * *$ & $0.04^{\mathrm{NS}}$ & $0.27^{\mathrm{Ns}}$ \\
\hline Method-5 ${ }^{(5)}$ & $-0.52 * *$ & $-0.90^{* *}$ & $0.01^{\mathrm{NS}}$ & $0.20^{\mathrm{NS}}$ \\
\hline Method-6(6) & $-0.84 * *$ & $0.85^{* *}$ & $0.04^{\mathrm{NS}}$ & $0.21^{\mathrm{NS}}$ \\
\hline Method- $7^{(7)}$ & $-0.15^{\mathrm{NS}}$ & $-0.83^{* *}$ & $0.39^{\mathrm{NS}}$ & $0.28^{\mathrm{NS}}$ \\
\hline \multicolumn{5}{|c|}{ 5-10 cm layer } \\
\hline Method-1 & $0.19^{\mathrm{NS}}$ & $-0.58^{* *}$ & $-0.26^{\mathrm{NS}}$ & $0.29^{\mathrm{NS}}$ \\
\hline Method-2 & $-0.03^{\mathrm{NS}}$ & $-0.84^{* *}$ & $-0.41^{*}$ & $0.52^{* *}$ \\
\hline Method-3 & $-0.63 * *$ & $-0.79 * *$ & $-0.30^{\mathrm{NS}}$ & $-0.05^{\mathrm{NS}}$ \\
\hline Method-4 & $-0.13^{\mathrm{NS}}$ & $-0.78^{* *}$ & $-0.24^{\mathrm{NS}}$ & $0.17^{\mathrm{NS}}$ \\
\hline Method-5 & $-0.09^{\mathrm{NS}}$ & $-0.86^{* *}$ & $-0.29^{\mathrm{NS}}$ & $0.26^{\mathrm{NS}}$ \\
\hline Method-6 & $-0.06^{\mathrm{NS}}$ & $-0.83^{* *}$ & $-0.19^{\mathrm{NS}}$ & $0.15^{\mathrm{NS}}$ \\
\hline Method-7 & $0.07^{\mathrm{NS}}$ & $-0.80 * *$ & $-0.33^{\mathrm{NS}}$ & $0.05^{\mathrm{NS}}$ \\
\hline \multicolumn{5}{|c|}{$10-20 \mathrm{~cm}$ layer } \\
\hline Method-1 & $0.17^{\mathrm{NS}}$ & $-0.87 * *$ & $-0.53^{* *}$ & $-0.24^{\mathrm{NS}}$ \\
\hline Method-2 & $0.09^{\mathrm{NS}}$ & $-0.84^{* *}$ & $-0.51 *$ & $0.17^{\mathrm{NS}}$ \\
\hline Method-3 & $-0.35^{\mathrm{NS}}$ & $-0.78^{* *}$ & $-0.47^{*}$ & $-0.44^{* *}$ \\
\hline Method-4 & $0.04^{\mathrm{NS}}$ & $-0.78^{* *}$ & $-0.36^{\mathrm{NS}}$ & $-0.14^{\mathrm{NS}}$ \\
\hline Method-5 & $0.18^{\mathrm{NS}}$ & $-0.73 * *$ & $-0.36^{\mathrm{NS}}$ & $-0.34^{\mathrm{NS}}$ \\
\hline Method-6 & $0.17^{\mathrm{NS}}$ & $-0.49 *$ & $-0.26^{\mathrm{NS}}$ & $-0.20^{\mathrm{NS}}$ \\
\hline Method-7 & $0.02^{\mathrm{NS}}$ & $-0.65^{* *}$ & $-0.41^{*}$ & $-0.34^{\mathrm{NS}}$ \\
\hline
\end{tabular}

(1)Method-1: extraction by DTPA-TEA solution at $\mathrm{pH} 7.3$ (2:1 extractant/soil ratio). (2)Method-2: extraction by DTPA-TEA solution at $\mathrm{pH} 7.3$ (5:1 extractant/soil ratio). ${ }^{(3)}$ Method-3: extraction by Mehlich-1 solution (5:1 extractant/soil ratio). ${ }^{(4)}$ Method-4: extraction by Mehlich-1 solution (10:1 extractant/soil ratio). ${ }^{(5)}$ Method-5: extraction by $0.1 \mathrm{~mol} \mathrm{~L}^{-1} \mathrm{HCl}$ solution (5:1 extractant/soil ratio). ${ }^{(6)}$ Method-6: extraction by $0.1 \mathrm{~mol} \mathrm{~L}-1 \mathrm{HCl}$ solution (10:1 extractant/soil ratio). ${ }^{(7)}$ Method-7: extraction by Mehlich-3 solution (10:1 extractant/soil ratio). NS: not significant, ${ }^{*} p<0.05$, and $* * p<0.01$.

fects is that an increase in soil $\mathrm{pH}$ as a consequence of liming can have enhanced microbial activity, increasing dissolved organic matter (Filep et al., 2003) and, consequently, improving solubility of $\mathrm{Cu}$ bounded to the low molecular-weight organic compounds.

Soil extractable Fe by DTPA-TEA solution (2:1 and 5:1), Mehlich-1 solution (10:1), and $0.1 \mathrm{~mol} \mathrm{~L}^{-1} \mathrm{HCl}$ solution $(5: 1$ and $10: 1)$ at $0-5 \mathrm{~cm}$ layer was influenced by the interactions between lime rates $\left(0,2,4\right.$, and $\left.6 \mathrm{Mg} \mathrm{ha}^{-1}\right)$ and re-liming ( 0 and $3 \mathrm{Mg} \mathrm{ha}^{-1}$ ) (Figure 2). Lower concentrations of soil extractable $\mathrm{Fe}$ was observed on the re-limed plots. For the other studied extractants and layers, liming caused linear decrease of the extractable Fe concentrations (Figure 2). In addition, negative correlations were observed between concentrations of extractable $\mathrm{Fe}$ and soil $\mathrm{pH}$ for all studied layers (Table 1). Ferric $\left(\mathrm{Fe}^{3+}\right)$ and ferrous $\left(\mathrm{Fe}^{2+}\right)$ activity in the soil solution decrease 1000-fold and 100-fold, respectively, for each unit increase in soil $\mathrm{pH}$ (Lindsay, 1979; Fageria et al., 2002). Alleoni et al. (2005) also observed a decrease in Fe concentrations extracted by DTPA-TEA (2:1 extractant/soil ratio) at the $10 \mathrm{~cm}$ soil layer after surface liming application under NT system.

No interactions were observed between lime rates $\left(0,2,4\right.$, and $\left.6 \mathrm{Mg} \mathrm{ha}^{-1}\right)$ and re-liming $\left(0\right.$ and $\left.3 \mathrm{Mg} \mathrm{ha}^{-1}\right)$ to Mn extracted by different procedures (Figure 3). All extractants indicate that increasing surface lime rate increased quadratically extractable $\mathrm{Mn}$ concentration at $0-5 \mathrm{~cm}$ layer (Figure 3). Surface liming probably caused an increase on microbial activity and on dissolved organic matter (Filep et al., 2003) at the soil surface. Increased microbial activity can also result in a decrease in the oxidation-reduction potential of the soil, increasing $\mathrm{Mn}$ availability (Stevenson, 1986); consequently, manganese (II) forms only relatively weak bounds with organic ligands (Marschner, 1995). In all extraction meth- 


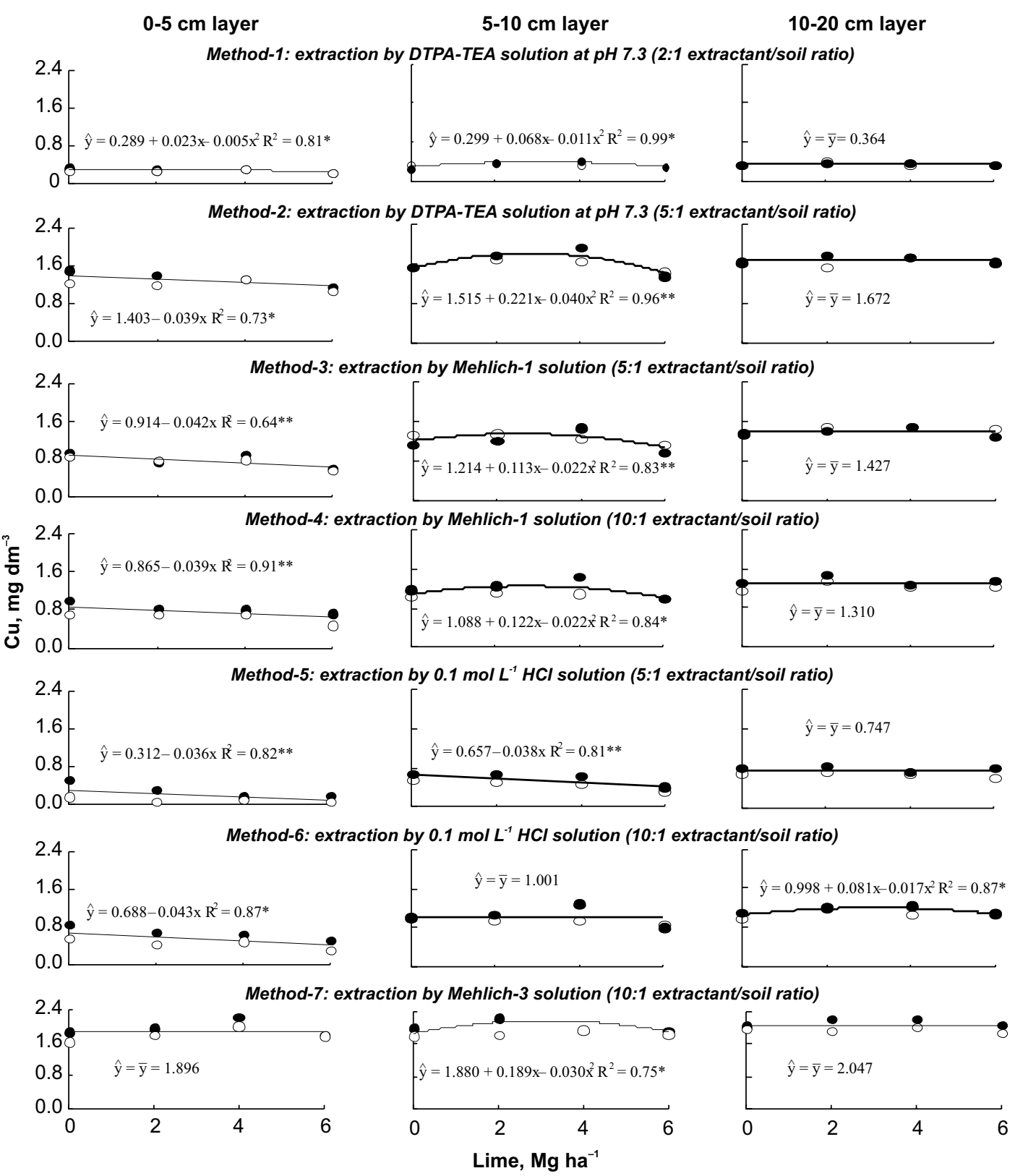

Figure 1 - Soil copper $(\mathrm{Cu})$ concentrations extracted by different procedures as affected by surface-applied lime rates, without $(\bullet)$ and with (O) surface re-liming at the rate of $3 \mathrm{Mg} \mathrm{ha}^{-1} .{ }^{*} p<0.05$ and ${ }^{* *} p<0.01$.

ods, no reductions in extractable $\mathrm{Mn}$ at the soil surface layer $(0-5 \mathrm{~cm})$ were detected from surface application of lime. However, increasing surface lime rate decreased linearly Mn concentration extracted by DTPA-TEA solution $(5: 1)$ at $5-10 \mathrm{~cm}$ layer, and by DTPA-TEA solution (2:1 and 5:1), $0.1 \mathrm{~mol} \mathrm{~L}^{-1} \mathrm{HCl}$ solution (5:1 and 10:1) and Mehlich-3 solution at $10-20 \mathrm{~cm}$ layer. In these cases, negative correlations were generally observed between concentrations of extractable $\mathrm{Mn}$ and soil $\mathrm{pH}$, mainly, below the $5 \mathrm{~cm}$ depth (Table 1). According to Fageria et al. (2002), the main ionic Mn species in a soil solution is $\mathrm{Mn}^{2+}$, and its concentrations decrease 100-fold for each unit increase in soil $\mathrm{pH}$.

The various soil extractable $\mathrm{Zn}$ concentrations (Method-1 to Method-7) were not influenced by the inter- action between lime rates $\left(0,2,4\right.$, and $\left.6 \mathrm{Mg} \mathrm{ha}^{-1}\right)$ and reliming $\left(0\right.$ and $\left.3 \mathrm{Mg} \mathrm{ha}^{-1}\right)$ (Figure 4). Increasing surface lime rate increased linearly $\mathrm{Zn}$ concentrations extracted by DTPA-TEA solution $(5: 1)$ at $5-10 \mathrm{~cm}$ layer. This can be interpreted as a direct effect of the high chelation capacity as proportioned by $5: 1$ solution/soil ratio used in Method-2. Norvell (1984) proposed to use a greater solution/soil ratio to compensate the limitations of extractants, mainly of their chelation capacity in soil at low $\mathrm{pH}$. For the other depths and procedures, changes on extractable $\mathrm{Zn}$ concentrations after liming treatments were not observed. Acid extractants have normally not been efficient to detect slight changes in extractable $\mathrm{Zn}$ as a consequence of liming, becoming a hard task to select an adequate extractant for this micronutrient (Abreu et al., 2007). 


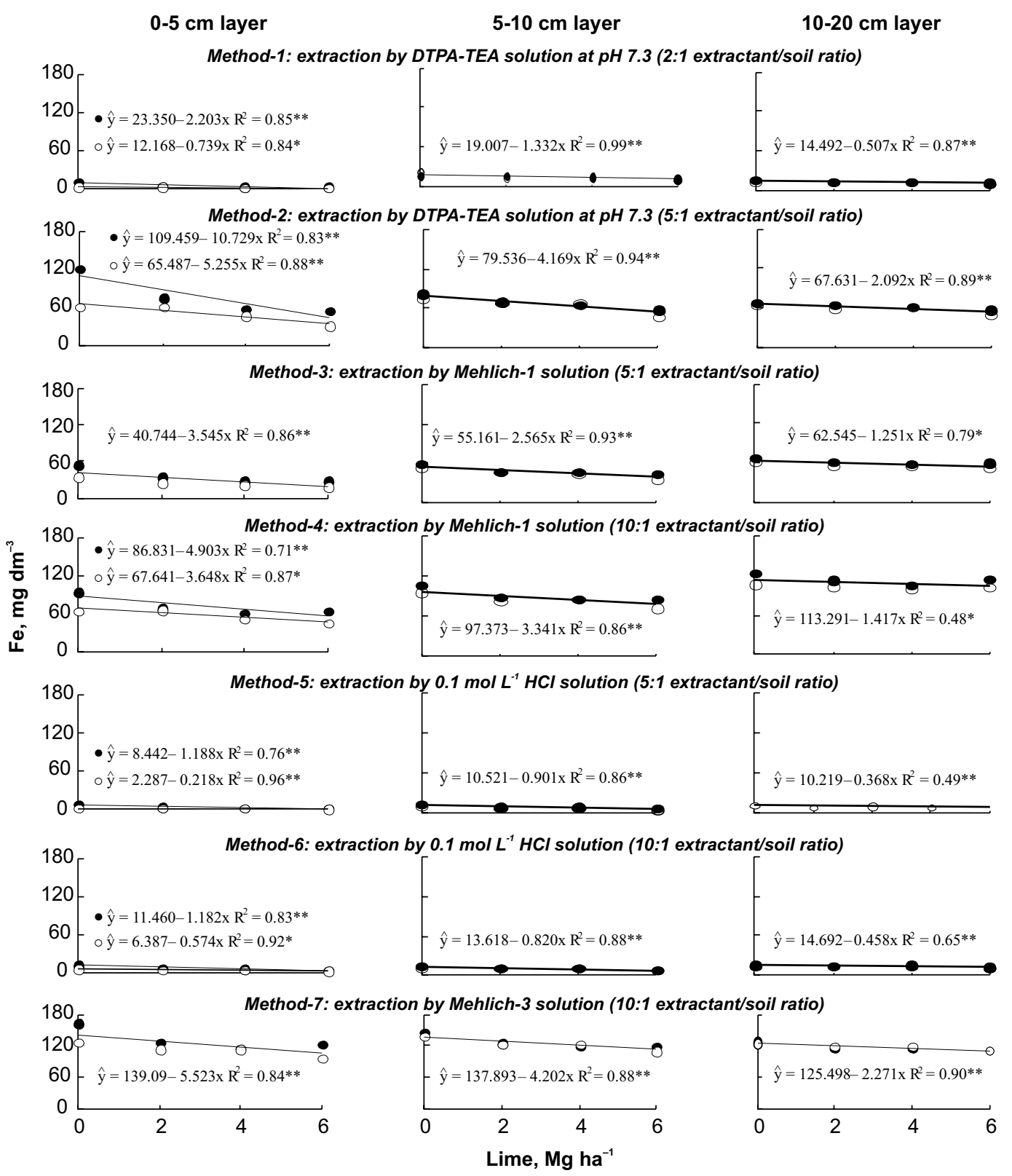

Figure 2 - Soil iron $(\mathrm{Fe})$ concentrations extracted by different procedures as affected by surface-applied lime rates, without $(\bullet)$ and with $(\mathrm{O})$ surface re-liming at the rate of $3 \mathrm{Mg} \mathrm{ha}^{-1}$. ${ }^{*} p<0.05$ and $* \%<0.01$.

The mean capacity of the evaluated solutions to extract soil $\mathrm{Cu}$ followed this order at $0-5 \mathrm{~cm}$ layer (Table 2): Mehlich-3 solution > DTPA-TEA solution (5:1) > Mehlich-1 solution (5:1) $\cong$ Mehlich-1 solution (10:1) > $0.1 \mathrm{~mol} \mathrm{~L}^{-1} \mathrm{HCl}$ solution (10:1) > DTPA-TEA solution $(2: 1)>0.1 \mathrm{~mol} \mathrm{~L}^{-1} \mathrm{HCl}$ solution (5:1). At the 5-10 and $10-20 \mathrm{~cm}$ layers this order was similar; only the $0.1 \mathrm{~mol}$ $\mathrm{L}^{-1} \mathrm{HCl}$ solution (5:1) extracted more $\mathrm{Cu}$ than the DTPA-TEA solution (2:1). The Mehlich-3 solution demonstrated a greater capacity of extraction in comparison to the other extractants, which is in agreement with Abreu et al. (1996). Because of the acid reagents and chelates, such as EDTA, it is expected higher amounts of micronutrients when they are extracted by the Mehlich3 solution than by the DTPA-TEA (Vidal-Vázquez et al.,
2005) and by diluted acids (e.g. Mehlich-1 and $\mathrm{HCl}$ ) (Abreu et al., 2002). Diluted acid solutions may only partially solubilize soil's $\mathrm{Cu}$, while chelating agents such as DTPA or EDTA reduce the $\mathrm{Cu}$ activity in solution by complexation, causing the dissolution of the labile forms of $\mathrm{Cu}$ in soils (Abreu et al., 1998). Also, a greater solution/soil ratio induces an increase in extraction capacity, except for Mehlich-1 solution (Table 2).

Soil $\mathrm{Fe}$ concentrations occurred in the following order at $0-5$ and $5-10 \mathrm{~cm}$ layers, considering the extraction mean capacity of various solutions (Table 2): Mehlich-3 solution > Mehlich-1 solution (10:1) > DTPA-TEA solution (5:1) > Mehlich-1 solution (5:1) > DTPA-TEA solution $(2: 1)>0.1 \mathrm{~mol} \mathrm{~L}^{-1} \mathrm{HCl}$ solution $(10: 1)>0.1 \mathrm{~mol}$ $\mathrm{L}^{-1} \mathrm{HCl}$ solution (5:1). At the layer of $10-20 \mathrm{~cm}$ this order 


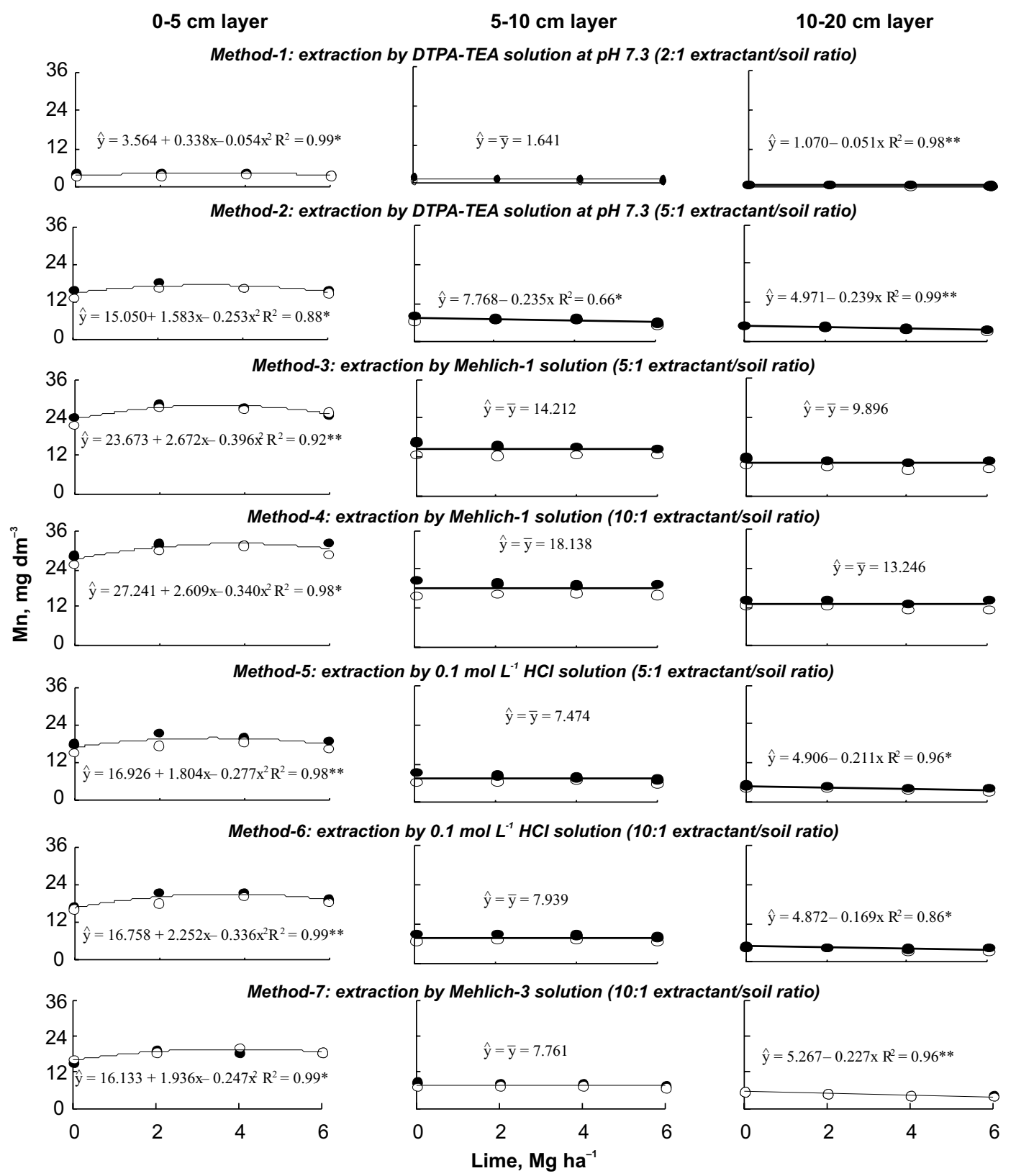

Figure 3 - Soil manganese (Mn) concentrations extracted by different procedures as affected by surface-applied lime rates, without $(\bullet)$ and with (O) surface re-liming at the rate of $3 \mathrm{Mg} \mathrm{ha}^{-1} . * p<0.05$ and $* * p<0.01$.

was similar; only the $0.1 \mathrm{~mol} \mathrm{~L}^{-1} \mathrm{HCl}$ solution (10:1) extracted slightly more Fe than the DTPA-TEA solution (2:1). Abreu et al. (2004) verified that extracting the Fe followed this order: Mehlich-3 > Mehlich-1 (5:1 extractant/ soil ratio) > DTPA-TEA (2:1 extractant/soil ratio). Similar results were also observed by Rodrigues et al. (2001).

The order of the Mn extraction, according to the mean capacity of the various solutions and to the 0-5, 510 , and 10-20 cm layers was the following (Table 2): Mehlich-1 solution (10:1) > Mehlich-1 solution (5:1) > $0.1 \mathrm{~mol} \mathrm{~L}^{-1} \mathrm{HCl}$ solution (10:1) Mehlich-3 solution $\cong$ $0.1 \mathrm{~mol} \mathrm{~L}^{-1} \mathrm{HCl}$ solution $(5: 1) \cong$ DTPA-TEA solution (5:1) > DTPA-TEA solution (2:1). Abreu et al. (2004) also observed that Mehlich-1 (5:1 extractant/soil ratio) solution extracted more $\mathrm{Mn}$ than Mehlich-3 solution. On the other hand, Rodrigues et al. (2001) found that the Mehlich-3 solution have a higher Mn extraction capacity than the DTPA-TEA (2:1 extractant/soil ratio) solution and Mehlich-1 (5:1 extractant/soil ratio) solution.

The mean capacity of the evaluated solutions when extracting the $\mathrm{Zn}$ from the soil followed this order at 0 $5 \mathrm{~cm}$ layer: DTPA-TEA solution $(5: 1) \cong$ Mehlich-1 solution (5:1) $\cong$ Mehlich-3 solution > Mehlich-1 solution $(10: 1) \cong 0.1 \mathrm{~mol} \mathrm{~L}^{-1} \mathrm{HCl}$ solution $(5: 1)>0.1 \mathrm{~mol} \mathrm{~L}^{-1} \mathrm{HCl}$ solution (10:1) > DTPA-TEA solution (2:1). At the layer of $5-10 \mathrm{~cm}$ this order was: DTPA-TEA solution $(5: 1) \cong$ Mehlich-1 solution $(5: 1) \cong 0.1 \mathrm{~mol} \mathrm{~L}^{-1} \mathrm{HCl}$ solution $(5: 1)$ $\cong$ Mehlich-1 solution (10:1) Mehlich-3 solution $\cong 0.1$ mol L ${ }^{-1} \mathrm{HCl}$ solution (10:1) > DTPA-TEA solution (2:1). At the layer of $10-20 \mathrm{~cm}$ this order was: Mehlich-1 solu- 


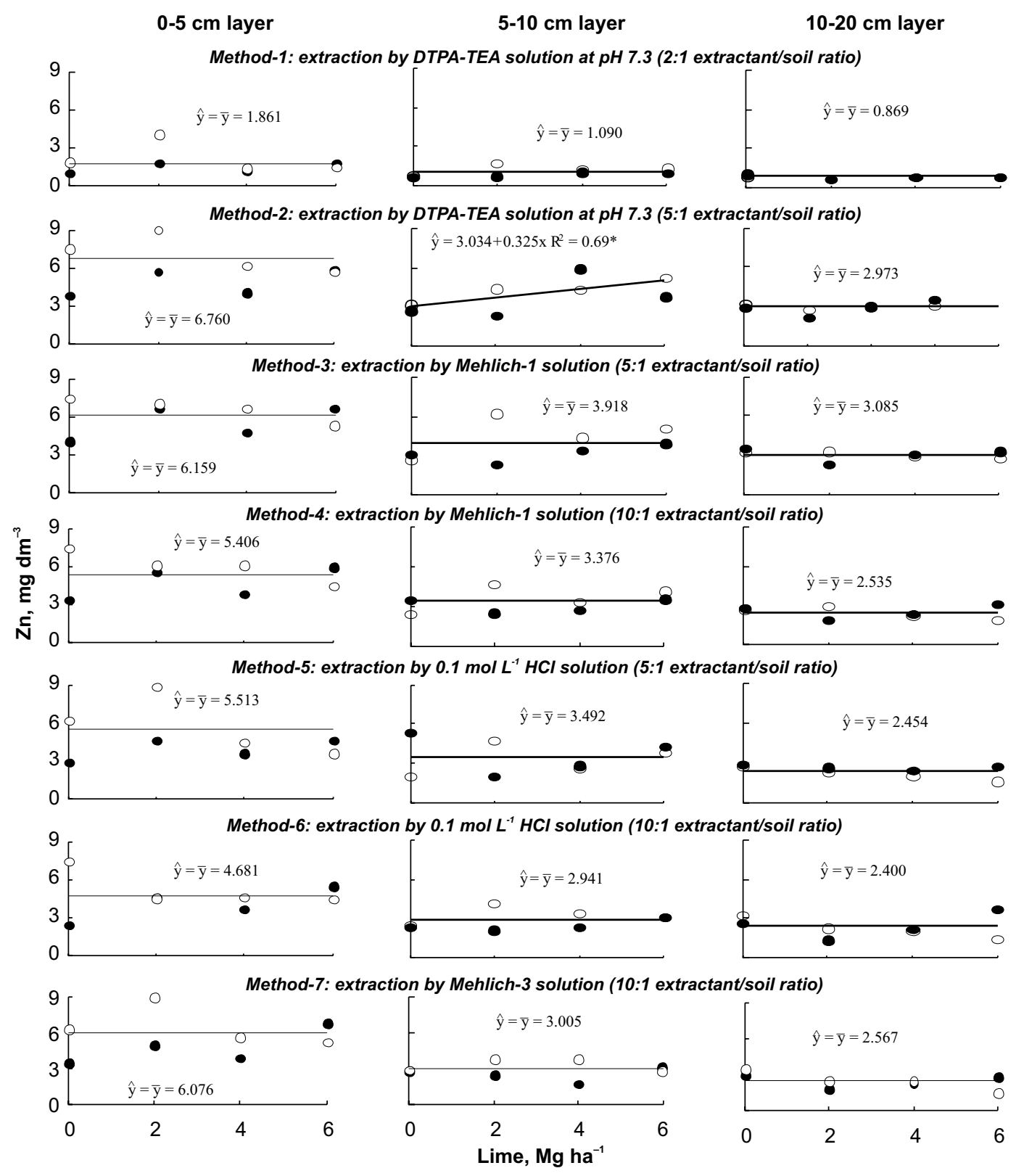

Figure 4 - Soil zinc $(\mathrm{Zn})$ concentrations extracted by different procedures as affected by surface-applied lime rates, without $(\bullet)$ and with (O) surface re-liming at the rate of $3 \mathrm{Mg} \mathrm{ha}^{-1} .{ }^{*} p<0.05$.

tion $(5: 1) \cong$ DTPA-TEA solution $(5: 1) \cong$ Mehlich-3 solution $\cong$ Mehlich-1 solution $(10: 1) \cong 0.1 \mathrm{~mol} \mathrm{~L}-1 \mathrm{HCl}$ solution $(5: 1) \cong 0.1 \mathrm{~mol} \mathrm{~L}^{-1} \mathrm{HCl}$ solution $(10: 1)>$ DTPATEA solution (2:1). Wang et al. (2004) also observed that Mehlich-3 solution extracted more $\mathrm{Zn}$ than DTPA-TEA (2:1 solution/soil ration). Abreu et al. (2002) also verified that extracting the $\mathrm{Zn}$ followed this order: Mehlich1 (5:1 extractant/soil ratio) > Mehlich-3 > DTPA-TEA (2:1 extractant/soil ratio). Diluted strong acids (as with Mehlich-1 and Mehlich-3 solutions) apparently dissolved partially the $\mathrm{Zn}$ contained in the soil solid phase (Abreu et al., 2002). Moreover, $\mathrm{HCl}$ solution may preferentially remove $\mathrm{Zn}$ from mineral surfaces while EDTA and DTPA may remove $\mathrm{Zn}$ preferentially from the soil organic matter (Haynes, 1997).
Micronutrients in the wheat leaves

The 1993 liming and the 2000 re-liming treatments did not affect the $\mathrm{Cu}, \mathrm{Fe}$ and $\mathrm{Zn}$ concentrations in the wheat leaves in 2003 (Figure 5). However, Mn concentration in the leaves was influenced by the interaction between lime rates $\left(0,2,4\right.$, and $\left.6 \mathrm{Mg} \mathrm{ha}^{-1}\right)$ and re-liming $\left(0\right.$ and $\left.3 \mathrm{Mg} \mathrm{ha}^{-1}\right)$. Increasing the surface liming rate decreased linearly $\mathrm{Mn}$ concentration in the wheat leaves both in the plots with or without re-liming. Surface reliming caused a decrease in $\mathrm{Mn}$ concentration in the wheat leaves, mainly in the plots not limed in 1993. However, these observed Mn concentrations were adequate for wheat, according to Malavolta et al. (1997).

Surface liming application under NT systems has been shown to decrease the plant's Mn uptake (Caires 

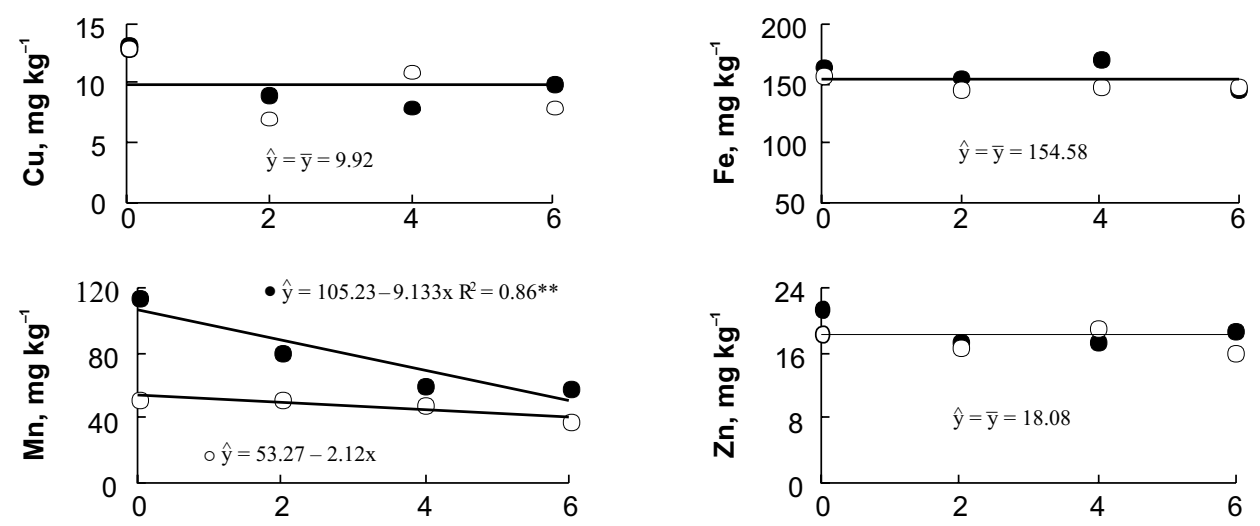

Lime, $\mathrm{Mg} \mathrm{ha}^{-1}$

Figure 5 - Copper $(\mathrm{Cu})$, iron $(\mathrm{Fe})$, manganese $(\mathrm{Mn})$, and zinc $(\mathrm{Zn})$ concentrations in wheat leaves as affected by surface-applied lime rates, without $(\bullet)$ and with $(O)$ surface re-liming at the rate of $3 \mathrm{Mg} \mathrm{ha}^{-1}$. $* * p<0.01$.

Table 2 - Minimal (Min), maximum (Max) and mean of cationic micronutrients concentrations in soil considering all treatments, in different layers, after liming and re-liming according to extraction methods.

\begin{tabular}{|c|c|c|c|c|c|c|c|c|c|c|c|c|}
\hline \multirow{2}{*}{ Method } & \multicolumn{3}{|c|}{ Copper $(\mathrm{Cu})$} & \multicolumn{3}{|c|}{ Iron $(\mathrm{Fe}$} & \multicolumn{3}{|c|}{ Manganese (Mn) } & \multicolumn{3}{|c|}{ Zinc $(\mathrm{Zn})$} \\
\hline & Min & Max & Mean & Min & Max & Mean & Min & Max & Mean & Min & Max & Mean \\
\hline & \multicolumn{12}{|c|}{ - } \\
\hline \multicolumn{13}{|l|}{$0-5 \mathrm{~cm}$ layer } \\
\hline Method-1 ${ }^{(1)}$ & 0.20 & 0.38 & 0.28 & 6.11 & 29.24 & 13.35 & 3.02 & 5.12 & 3.83 & 0.70 & 9.77 & 1.86 \\
\hline Method-2(2) & 1.02 & 1.67 & 1.29 & 26.86 & 137.90 & 63.50 & 13.20 & 20.40 & 16.26 & 2.26 & 35.08 & 6.76 \\
\hline Method-3 $3^{(3)}$ & 0.49 & 1.11 & 0.79 & 13.38 & 60.73 & 30.11 & 20.48 & 30.93 & 26.14 & 2.60 & 10.72 & 6.16 \\
\hline Method-4 ${ }^{(4)}$ & 0.44 & 1.13 & 0.75 & 43.66 & 99.07 & 64.41 & 22.79 & 36.18 & 30.31 & 2.14 & 9.73 & 5.41 \\
\hline Method-5 ${ }^{(5)}$ & 0.02 & 0.66 & 0.20 & 0.55 & 12.69 & 3.25 & 14.35 & 22.49 & 18.46 & 1.91 & 20.19 & 5.10 \\
\hline Method-6(6) & 0.22 & 0.89 & 0.56 & 1.73 & 16.08 & 6.29 & 14.09 & 23.49 & 19.41 & 1.97 & 9.79 & 4.68 \\
\hline Method- $7^{(7)}$ & 1.49 & 2.74 & 1.90 & 88.74 & 187.66 & 122.44 & 13.06 & 22.23 & 18.48 & 2.81 & 26.71 & 6.08 \\
\hline \multicolumn{13}{|c|}{ 5-10 cm layer } \\
\hline Method-1 & 0.10 & 0.48 & 0.35 & 7.69 & 28.27 & 15.01 & 0.80 & 4.48 & 1.64 & 0.39 & 2.36 & 1.09 \\
\hline Method-2 & 1.06 & 2.17 & 1.63 & 43.86 & 90.13 & 67.03 & 3.87 & 9.17 & 7.06 & 1.83 & 7.60 & 4.01 \\
\hline Method-3 & 0.91 & 1.70 & 1.24 & 32.33 & 66.60 & 47.46 & 9.45 & 17.93 & 14.21 & 1.67 & 10.25 & 3.92 \\
\hline Method-4 & 0.79 & 1.68 & 1.14 & 63.31 & 111.31 & 87.35 & 13.06 & 21.94 & 18.14 & 1.34 & 6.92 & 3.38 \\
\hline Method-5 & 0.27 & 0.77 & 0.54 & 3.32 & 16.18 & 7.82 & 4.56 & 10.69 & 7.47 & 1.25 & 10.69 & 3.49 \\
\hline Method-6 & 0.56 & 1.59 & 1.00 & 6.79 & 19.02 & 11.16 & 4.63 & 11.08 & 7.94 & 0.94 & 8.49 & 2.94 \\
\hline Method-7 & 1.51 & 2.84 & 2.02 & 100.87 & 157.83 & 125.29 & 5.62 & 9.63 & 7.76 & 1.23 & 7.20 & 3.01 \\
\hline \multicolumn{13}{|c|}{$10-20 \mathrm{~cm}$ layer } \\
\hline Method-1 & 0.27 & 0.45 & 0.36 & 9.58 & 17.05 & 12.97 & 0.56 & 1.50 & 0.92 & 0.55 & 1.42 & 0.87 \\
\hline Method-2 & 1.07 & 2.04 & 1.67 & 47.68 & 73.50 & 61.36 & 2.72 & 6.12 & 4.25 & 1.64 & 5.00 & 2.97 \\
\hline Method-3 & 1.10 & 1.65 & 1.43 & 46.59 & 75.37 & 58.80 & 6.32 & 14.19 & 9.90 & 1.72 & 4.82 & 3.09 \\
\hline Method-4 & 1.01 & 1.70 & 1.30 & 85.36 & 127.85 & 109.04 & 9.15 & 17.33 & 13.25 & 1.22 & 5.84 & 2.54 \\
\hline Method-5 & 0.54 & 1.02 & 0.75 & 6.85 & 13.05 & 9.12 & 2.36 & 6.99 & 4.27 & 1.29 & 5.12 & 2.45 \\
\hline Method-6 & 0.83 & 1.34 & 1.12 & 10.76 & 16.27 & 13.32 & 2.40 & 6.15 & 4.36 & 0.79 & 7.18 & 2.40 \\
\hline Method-7 & 1.61 & 2.48 & 2.05 & 101.03 & 145.37 & 118.69 & 3.06 & 6.65 & 4.59 & 1.16 & 6.23 & 2.57 \\
\hline
\end{tabular}


\& Da Fonseca, 2000; Godsey et al., 2007; Caires et al., 2008). This may be due to a decrease its concentration due to a decrease on the bioavailable form in the soil solution due to a soil $\mathrm{pH}$ increase. In all studied methods, no decreases were detected in extractable $\mathrm{Mn}$ at the 0-5 $\mathrm{cm}$ soil layer due to an increase in soil $\mathrm{pH}$ as a consequence of a surface liming (Figure 3). Increasing surface lime rate only decreased $\mathrm{Mn}$ concentration extracted by DTPA-TEA solution (5:1) at $5-10 \mathrm{~cm}$ layer, and by DTPATEA solution (2:1 and 5:1), $0.1 \mathrm{~mol} \mathrm{~L}^{-1} \mathrm{HCl}$ solution (5:1 and 10:1) and Mehlich-3 solution at 10-20 cm layer. So, the solutions of DTPA-TEA, Mehlich-1, Mehlich-3, and $\mathrm{HCl}$ were ineffective to detect important decreases in soil $\mathrm{Mn}$ availability pursuant to the surface-applied lime.

Changes in cationic micronutrients availability at the soil most superficial layers after liming affect the mineral nutrition of plants, mainly under NT systems (Caires \& Da Fonseca, 2000; Godsey et al., 2007; Caires et al., 2008). However, the cationic micronutrients concentrations extracted by the DTPA-TEA, Mehlich-1, Mehlich-3, and $\mathrm{HCl}$ solutions after the surface lime application under a NT system cannot represent the available amount to the crops. Our study highlight the difficulty of selecting a procedure for the extraction of these micronutrients that would be more appropriated to predict their cationic micronutrients bioavailability. This is in agreement with the results obtained in other studies in Brazilian soils (Vidal-Vázquez et al., 2005; Nascimento et al., 2006; Abreu et al., 2007).

\section{Acknowledgements}

To FAPESP, CNPq, and CAPES for providing scholarships to the authors. To Department of Soil Science from USP/ESALQ because of allowing the use of ICP-OES.

\section{References}

Abreu, C.A.; Novais, R.F.; Raij, B. van; Ribeiro, A.C. 1994. Influência da reação do solo na extração de manganês por diferentes extratores químicos. Revista Brasileira de Ciência do Solo 18: 91-99.

Abreu, C.A.; Raij, B. van; Abreu, M.F.; Santos, W.R.; Andrade, J.C. 1996. Efficiency of multinutrient extractants for the determination of available copper in soils. Communications in Soil Science and Plant Analysis 27: 763-771.

Abreu, C.A.; Abreu, M.F.; Andrade, J.C.; Raij, B. van. 1998. Restrictions in the use of correlation coefficients in comparing methods for the determination of the micronutrients in soils. Communications in Soil Science and Plant Analysis 29: 19611972.

Abreu, C.A.; Raij, B. van; Gabe, U.; Abreu, M.F.; Paz-González, A. 2002. Efficiency of multinutrient extractants for the determining of available zinc in soils. Communications in Soil Science and Plant Analysis 33: 3313-3324.

Abreu, C.A.; Raij, B. van; Abreu, M. F.; Paz-González, A. 2004. Avaliação da disponibilidade de manganês e ferro em solos pelo uso do método modificado da resina de troca iônica. Revista Brasileira de Ciência do Solo 28: 579-584.

Abreu, C.A.; Lopes, A.S.; Santos, G.C.G. 2007. Micronutrientes. p.645-736. In: Novais, R.F.; Alvarez V., V.H.; Barros, N.F.; Fontes, R.L.F.; Cantarutti, R.B.; Neves, J.C.L., eds. Fertilidade do solo. Sociedade Brasileira de Ciência do Solo, Viçosa, MG, Brazil.
Alleoni, L.R.F.; Cambri, M.A.; Caires, E.F. 2005. Atributos químicos de um Latossolo de Cerrado sob plantio direto de acordo com doses e formas de aplicação de calcário. Revista Brasileira de Ciência do Solo 29: 923-934.

Bataglia, O.C.; Raij, B. van. 1989. Eficiência de extratores de micronutrientes na análise de solo. Revista Brasileira de Ciência do Solo 13: 205-212.

Bataglia, O.C.; Teixeira, J.P.F.; Furlani, P.R.; Furlani, A.N.C.; Gallo, J.R. 1978. Métodos de Análise Química de Plantas. Instituto Agronômico de Campinas [IAC], Campinas, SP, Brasil.

Bernardi, A.C.C.; Silva, C.A.; Pérez, D.V.; Meneguelli, N.A. 2002. Analytical quality program of soil fertility laboratories that adopt Embrapa methods in Brazil. Communications in Soil Science and Plant Analysis 33: 2661-2672.

Caires, E.F.; Da Fonseca, A.F. 2000. Absorção de nutrientes pela soja cultivada no sistema de plantio direto em função da calagem na superfície. Bragantia 59: 213-220.

Caires, E.F.; Banzatto, D.A.; Da Fonseca, A.F. 2000. Calagem na superfície em sistema plantio direto. Revista Brasileira de Ciência do Solo 24: 161-169.

Caires, E.F.; Alleoni, L.R.F.; Cambri, M.A.; Barth, G. 2005. Surface application of lime for crop grain production under a no-till system. Agronomy Journal 97: 791-798.

Caires, E.F.; Barth, G.; Garbuio, F.J. 2006a. Lime application in the establishment of a no-till system for grain crop production in Southern Brazil. Soil \& Tillage Research 89: 3-12.

Caires, E.F.; Corrêa, J.C.L.; Churka, S.; Barth, G.; Garbuio, F.J. 2006b. Surface application of lime ameliorates subsoil acidity and improves root growth and yield of wheat in an acid soil under no-till system. Scientia Agricola 63: 502-509.

Caires, E.F.; Garbuio, F.J; Barth, G. 2008. Surface application of lime and cover black oat and corn residues for no-till soybean production. Communications in Soil Science and Plant Analysis 39: 2102-2118.

Camargo, O.A.; Valadares, J.M.A.S.; Dechen, A.R. 1982. Efeito do $\mathrm{pH}$ e da incubação na extração de manganês, zinco, cobre e ferro do solo. Revista Brasileira de Ciência do Solo 6: 83-88.

Fageria, N.K.; Baligar, V.C.; Clark, R.B. 2002. Micronutrients in crop production. Advances in Agronomy 77: 185-268.

Filep, T.; Kincses, I.; Nagy, P.T. 2003. Dissolved organic carbon (DOC) and dissolved organic nitrogen (DON) content of an Arenosol as affected by liming in a pot experiment. Archives of Agronomy and Soil Science 9: 111-117.

Godsey, C.B.; Pierzynski, G.M.; Mengel, D.B.; Lamond, R.E. 2007. Management of soil acidity in no-till production systems through surface application of lime. Agronomy Journal 99: 764772.

Haynes, R.J. 1997. Micronutrient status of a group of soils in Canterbury, New Zealand, as measured by extraction with EDTA, DTPA and $\mathrm{HCl}$, and its relationship with plant response to applied $\mathrm{Cu}$ and $\mathrm{Zn}$. Journal of Agricultural Science 129: 325333.

Lindsay, W.L. 1979. Chemical Equilibria in Soils. John Wiley \& Sons, New York, NY, USA.

Lindsay, W.L.; Norvell, W.A. 1978. Development of a DTPA soil test for zinc, iron, manganese, and copper. Soil Science Society of America Journal 42: 421-428.

Malavolta, E.; Vitti, G.C.; Oliveira, S.A. 1997. Avaliação do Estado Nutricional das Plantas: Princípios e Aplicações. 2ed. Potafos, Piracicaba, SP, Brazil.

Marschner, H. 1995. Mineral Nutrition of Higher Plants. 2ed. Academic Press, San Diego, CA, USA:

Mehlich, A. 1984. Mehlich-3 soil test extractant: a modification of Mehlich-2 extractant. Communications in Soil Science and Plant Analysis 15: 1409-1416.

Nascimento, C.W.A.; Oliveira, A.B.; Ribeiro, M.R.; Melo, E.E.C. 2006. Distribution and availability of zinc and copper in benchmark soils of Pernambuco State, Brazil. Communications in Soil Science and Plant Analysis 37: 109-125. 
Norvell, W.A. 1984. Comparison of chelating agents as extractants for metals in diverse soil materials. Soil Science Society of America Journal 48: 1285-1292.

Osiname, O.A.; Schulte, E.E.; Corey, R.B. 1973. Soil tests for available copper and zinc in soils of Western Nigeria. Journal of the Science of Food and Agriculture 24: 1341-1349.

Pavan, M.A.; Bloch, M.F.; Zempulski, H.C.; Miyazawa, M.; Zocoler, D.C. 1992. Manual de Análise Química do Solo e Controle de Qualidade. Instituto Agronômico do Paraná [IAPAR], Londrina, PR, Brazil.

Rodrigues, M.R.L.; Malavolta, E.; Moreira, A. 2001. Comparação de soluções extratoras de ferro e manganês em solos da Amazônia. Pesquisa Agropecuária Brasileira 36: 143-149.

SAS Institute. 1999. SAS System: Release 8.02. SAS Institute, Cary, NC, USA.

Stevenson, F.J. 1986. Cycles of Soil: Carbon, Nitrogen, Phosphorus, Sulfur, Micronutrients. John Wiley \&Sons, New York, NY, USA.
Vidal-Vázquez, E.; Caridad-Cancela, R.; Taboada-Castro, M.M.; Paz-Donzález, A.; Abreu, C.A. 2005. Trace elements extracted by DTPA and Mehlich-3 from agricultural soils with and without compost additions. Communications in Soil Science and Plant Analysis 36: 717-727.

Wang, J.J.; Harrell, D.L.; Henderson, R.E.; Bell, P.F. 2004. Comparison of soil-test extractants for phosphorus, potassium, calcium, magnesium, sodium, zinc, copper, manganese, and iron in Louisiana soils. Communications in Soil Science and Plant Analysis 35: 145-160.

Zanão Júnior, L.A.; Lana, R.M.Q.; Guimarães, E.C. 2007. Variabilidade espacial do $\mathrm{pH}$, teores de matéria orgânica e micronutrientes em profundidades de amostragem num Latossolo Vermelho sob semeadura direta. Ciência Rural 37: 1000-1007.

Received November 24, 2008

Accepted July 27, 2009 